Rapid Reviews COVID-19

\title{
Reviews of "Interleukin-6 Receptor Antagonists in Critically III Patients with Covid-19 - Preliminary report"
}

\author{
Manish Sagar ${ }^{1}$, Mike Samsonov $^{2}$ \\ ${ }^{1}$ Boston University School of Medicine, Medicine, USA, \\ ${ }^{2}$ Associated Professor, Sechenov Moscow Medical Academy: Pervyj Moskovskij gosudarstvennyj \\ medicinskij universitet imeni I M Secenova, Pharmacology, Russian Federation
}

Published on: Mar 01, 2021

License: Creative Commons Attribution 4.0 International License (CC-BY 4.0). 
To read the original manuscript, click the link above.

Summary of Reviews: IL-6 receptor inhibitor therapy likely reduces morbidity and mortality in a select group of patients if used within 24 hours of worsening clinical status. Both reviewers considered the multi-center, placebo-controlled randomized control trial results to be strong.

\section{Reviewer 1 (Manish Sagar) | [0०ण}

\section{Reviewer 2 (Mike Samsonov) | प्र०ण}

\section{RR:C19 Strength of Evidence Scale Key}

$$
\begin{aligned}
& \text { प }
\end{aligned}
$$

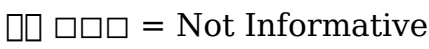

$$
\begin{aligned}
& \text { प्रा पर = Potentially Informative }
\end{aligned}
$$

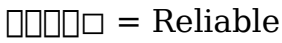

$$
\begin{aligned}
& \text { प्राप्र = Strong }
\end{aligned}
$$

To read the reviews, click the links below. 